\title{
Prevalence of primary and secondary infertility in the Colombo District
}

\author{
S. Samarakoon', "L. Rajapaksa ${ }^{2}$ and H. R. Seneviratne ${ }^{3}$ \\ The Ceylon Journal of Medical Science 2002; 45: 83-91
}

\begin{abstract}
Objective: To estimate the prevalence of primary and secondary infertility in the Colombo District

Design: A cross sectional survey

Setting: District of Colombo

Subjects: Two thousand currently married women of the reproductive age group

Measurements: Prevalence of primary and secondary infertility using the WHO definitions. When a woman has never conceived in spite of cohabitation and exposure to pregnancy for a period of twelve months; the condition was defined as primary infertility. Secondary infertility was defined as being present when a woman had previously conceived but had been unable to conceive subsequently despite cohabitation and exposure to pregnancy for a period of 24 months. If the woman had breast fed the previous infant, then exposure to pregnancy was calculated from the end of the period of lactation amenorrhoea.
\end{abstract}

Results: The point prevalence of primary infertility was estimated as $\mathbf{4 0 . 5}$ per 1000 married women of the reproductive age group, ( $95 \%$ C.L. $32.0-49.0$ per 1000 ). The prevalence increased progressively with increasing current age and age at marriage of women and their partners and was higher among employed women.

The point prevalence of secondary infertility was estimated as 160 per 1000 women of the repro- ductive age group, (95\% C.L. 143.9 - 176.0 per 1000 ). Increasing current age of women and their spouses, higher age at marriage of the male and low socio economic status were associated with increased prevalence. A history suggestive of post partum or post abortal infection was obtained in $20 \%$ of persons who were secondarily infertile.

Conclusions: Prevalence of primary infertility is low in the Colombo District, but amounts to an estimated 10,700 - 16,500 currently married women. The prevalence of secondary infertility is high, with post-partum and post-abortal infection contributing to a fifth of the cases.

\section{Introduction}

There is a paucity of information on the prevalence of primary and secondary infertility. The limited data available are derived from demographic sources and from clinical studies. Data derived from census is liable to be inaccurate as pregnancy wastage may be recorded as childlessness, or a childless woman may report an adopted offspring as her own during a census. Such estimates also assume that all currently married women are exposed to the risk of pregnancy.

Information from clinical sources suggest that infertility is an increasing problem in Sri Lanka. It is not clear whether there is a true increase in the number of infertile couples or more couples areseeking treatment as a result of improved services and a changing social environment

1. Consultant, STD/AIDS control programme, De Sarem Place, Colombo 8.

2. Professor, Department of Community Medicine, Faculty of Medicine, Colombo 8.

3. Professor, Department of Obstetrics and Gynaecology, Faculty of Medicine, Colombo 8.

"Author for correspondence 
which permits the acknowledgment of the problem. There may be a duplication of statistics as couples are known to move from one provider to another. Furthermore, cases identified in the hospital setting cannot be related to a definite geographic area or a population base and as such an estimation of incidence or prevalence is not possible. Thus, the present cross sectional community based survey was undertaken with the objective of estimating the prevalence of primary and secondary infertility.

\section{Methodology}

The target population consisted of an estimated 336,000 currently married women of the reproductive age group (15-49 years) (1) living within the Colombo District. Sample size was calculated assuming a prevalence of $3 \%$ as the world wide prevalence is estimated to be $2-10 \%,(2)$. Confidence limits (C.L.) for the estimate was set at $95 \%$ and margin of error at $\pm 1 \%$. Since a cluster sampling procedure was planned, the design factor was taken as 1.5 and a further $15 \%$ was added to account for possible non response (3). Sample size was thus calculated to be 2000 . The women were selected using a multi stage stratified cluster sampling procedure. A cluster included 40 women and was based in a Grama Sevaka area. Allocation of clusters was carried out probability proportional to size.

The unit of enumeration was the individual woman 15-49 years of age, currently married and resident in the household for at least 6 months. All such women living in an identified household were included in the study. Data were collected in respect of the woman identified and her spouse. Socio-demographic characteristics, a history of medical and gynaecological illness past or present, details of menstrual history, fertility patterns and a history of contraceptive use were obtained from the couple using a structured pretested questionnaire administered by trained interviewers. Informed consent was obtained from all individuals and ethical approval was obtained from the Ethical Review Committee of the Faculty of Medicine, University of Colombo. All couples identified as being infertile were offered investigation and treatment if they so desired.

The definitions given by the World Health Organization (WHO) were used to classify primary and secondary infertility. When a woman has never conceived in spite of cohabitation and exposure to pregnancy for a period of twelve months, the condition was defined as primary infertility. Secondary infertility was taken to be present when the woman had previously conceived but had been unable to conceive subsequently despite cohabitation and exposure to pregnancy for a period of 24 months. If the woman had breast fed the previous infant, then exposure to pregnancy was calculated from the end of the period of lactation amenorrhoea (4).

\section{Results}

The ages of the women in the sample ranged from 15-48 years while the range for men was 17-53 years. The modal age group was 30-34 years for both men and women, the mean age for the women was 30.4 years (SD=6.3 years) and for men 34.2 years ( $\mathrm{SD}=7.2$ years). The majority of the married women of the reproductive age group (MWRA) (76\%) and their spouses (75\%) were Sinhalese and $72 \%$ of the men and women were Buddhists. The distribution of these characteristics in the sample were very similar to that of the population of the district of Colombo recorded at the 1981 census (1).

\section{Primary infertility}

Of the $\mathbf{2 0 0 0}$ married couples studied, 81 women were found to fit the WHO definition of primary infertility. Thus the point prevalence of primary infertility was estimated to be 40.5 per 1000 married women of the reproductive age group (95\% C.L. 32 - 49 per 1000 married women of the 
reproductive age group). That is, within the Colombo district there are around $10,700-16,500$ married women in the reproductive age group who are considered infertile using the above definition.

The mean duration of infertility in this group was 2.2 years (S.D. 1.3 years). In $53 \%$ the duration of infertility was two to five years and a further $12 \%$ had failed to achieve conception after being exposed to the risk of pregnancy for 5 years or more.

Tables 1 and 2 show the association between selected socio-demographic characteristics and primary infertility. It is seen that the rate of primary infertility progressively increased with increasing current age and increasing age at marriage of women (Table 1) and their spouses (Table 2). The trends observed were statistically significant. There was no statistically significant difference in rates of infertility between those who reported menarche below 14 years and those who reported menarche at 14 years and over. The mean age at menarche in the sample population was 13.9 years, same as the results of a prospective study on a large sample of girls (5). Ethnicity of the women, level of education of the women and their spouses were not related to rates of infertility. Women who were employed had higher rates of infertility compared to those who were not, the difference being statistically significant. A significant difference was not seen in respect of men's employment, although high rates were seen among transport workers, clerks and commercial workers.

\section{Secondary infertility}

The study population included 1907 women who had previously conceived. Of these, 320 were considered to fit the WHO definition of secondary infertility and the point prevalence of secondary infertility was estimated to be 16 per 100 married women of the reproductive age group (C.L. 14.39 - 17.60).

Tables 3 and 4 examine the relationship between selected socio-demographic characteristics and secondary infertility. Increasing current age of both partners was associated with increase in secondary infertility, the trend observed being statistically significant. Age at marriage of the female was not seen to affect secondary infertility although a statistically significant trend was observed with increasing age at marriage of the male partner.

All women in the present study who were classified as secondary infertility were either Sinhala or Muslim and it was observed that the percentage affected were higher among the Muslims being $22.3 \%$ compared to $18.6 \%$ among the Sinhala ( $p$ $<0.05$ ). A statistically significant difference was also observed between those who reported menarche before 14 years and others, higher percentages being reported among those with early menarche.

Educational level of either partner or being a working woman showed no statistically significant association with secondary infertility. Prevalence was seen to be high when the men were labourers followed by those employed in the transport industry and in the service sector.

In the present sample $11.8 \%$ of the women reporting secondary infertility had symptoms suggestive of post-partum sepsis, and in a further $8.1 \%$ an abortion was followed by failure to conceive for a period of over 24 months i.e in 19.9\% the secondary infertility probably is a result of infection post-partum or post-abortion. 
Table 1. Distribution of primary infertility by selected characteristics of women

\begin{tabular}{|c|c|c|c|c|c|}
\hline Characteristic & $\begin{array}{l}\text { Number } \\
\text { of women }\end{array}$ & $\begin{array}{c}\text { Number of } \\
\text { women with } \\
\text { primary } \\
\text { infertility } \\
\end{array}$ & $\begin{array}{c}\% \text { of } \\
\text { primary } \\
\text { infertility }\end{array}$ & 95\% C. L. & $x 2$ for trend \\
\hline $\begin{array}{l}\text { Age group years } \\
15-19 \\
20-24 \\
25-29 \\
30-34 \\
>=35 \\
\text { Information not available }\end{array}$ & $\begin{array}{c}58 \\
333 \\
535 \\
558 \\
511 \\
5\end{array}$ & $\begin{array}{l}- \\
08 \\
21 \\
25 \\
27\end{array}$ & $\begin{array}{l}- \\
2.40 \\
3.92 \\
4.48 \\
5.28\end{array}$ & $\begin{array}{c}- \\
0.75-4.04 \\
2.27-5.56 \\
2.76-620 \\
3.34-7.22\end{array}$ & $\begin{array}{c}x 2=4.159 \\
p<0.05\end{array}$ \\
\hline $\begin{array}{l}\text { Age at marriage completed } \\
\text { years } \\
15-19 \\
20-24 \\
25-29 \\
30-34 \\
>=35 \\
\text { Information not available }\end{array}$ & $\begin{array}{c}507 \\
788 \\
509 \\
141 \\
49 \\
6\end{array}$ & $\begin{array}{l}09 \\
27 \\
28 \\
11 \\
06\end{array}$ & $\begin{array}{c}1.76 \\
3.43 \\
5.52 \\
7.80 \\
12.24\end{array}$ & $\begin{array}{c}0.62-2.92 \\
2.16-4.70 \\
3.52-7.48 \\
3.37-12.22 \\
3.06-21-42\end{array}$ & $\begin{array}{c}x 2=22.9013 \\
\mathrm{p}<0.001\end{array}$ \\
\hline $\begin{array}{l}\text { Age at menarche completed } \\
\text { years } \\
<14 \\
>=14 \\
\text { Information not available }\end{array}$ & $\begin{array}{c}993 \\
1002 \\
5\end{array}$ & $\begin{array}{l}48 \\
33\end{array}$ & $\begin{array}{l}4.83 \\
3.29\end{array}$ & $\begin{array}{l}3.50-6.16 \\
2.19-4.39\end{array}$ & $\begin{array}{c}x 2=2 . .80 \\
p=0.09\end{array}$ \\
\hline $\begin{array}{l}\text { Ethnicity } \\
\text { Sinhala } \\
\text { Tamil } \\
\text { Muslim } \\
\text { Malay } \\
\text { Other } \\
\text { Information not available }\end{array}$ & $\begin{array}{c}1516 \\
157 \\
242 \\
59 \\
26 \\
3\end{array}$ & $\begin{array}{l}66 \\
06 \\
08 \\
01 \\
-\end{array}$ & $\begin{array}{c}4.35 \\
3.82 \\
3.30 \\
1.69 \\
-\end{array}$ & $\begin{array}{c}3.32-5.38 \\
0.82-6.82 \\
1.04-5.55 \\
-1.59-4.97 \\
-\end{array}$ & $\begin{aligned} x 2 & =1.415 \\
p & =0.23\end{aligned}$ \\
\hline $\begin{array}{l}\text { Years of schooling } \\
\text { No schooling } \\
1-5 \\
6-9 \\
10+ \\
\text { Information not available }\end{array}$ & $\begin{array}{c}22 \\
205 \\
869 \\
900 \\
4\end{array}$ & $\begin{array}{l}- \\
04 \\
39 \\
38\end{array}$ & $\begin{array}{c}- \\
1.95 \\
4.48 \\
4.42\end{array}$ & $\begin{array}{c}- \\
0.05-3.84 \\
3.11-5.86 \\
2.90-53\end{array}$ & $\begin{array}{c}x 2=0.887 \\
\text { p. }>0.05\end{array}$ \\
\hline $\begin{array}{l}\text { Occupation } \\
\text { Working } \\
\text { Non working } \\
\text { Information not available }\end{array}$ & $\begin{array}{c}224 \\
1774 \\
2\end{array}$ & $\begin{array}{l}20 \\
61\end{array}$ & $\begin{array}{c}8.93 \\
3.4\end{array}$ & $\begin{array}{c}5.20-12.66 \\
2.59-4.28\end{array}$ & $\begin{array}{c}x 2=15.41 \\
p=0.0009\end{array}$ \\
\hline
\end{tabular}

$\mathrm{CL}=$ Confidence limits 
Table 2. Distribution of primary infertility by selected characteristics of men

\begin{tabular}{|c|c|c|c|c|c|}
\hline Characteristic & $\begin{array}{l}\text { Number } \\
\text { of men }\end{array}$ & $\begin{array}{c}\text { Number of } \\
\text { spouses with } \\
\text { primary } \\
\text { infertile } \\
\text { women }\end{array}$ & $\begin{array}{c}\% \text { of } \\
\text { primary } \\
\text { infertility }\end{array}$ & 95\% C.L. & $x 2$ for trend \\
\hline $\begin{array}{l}\text { Age group years } \\
15-19 \\
20-24 \\
25-29 \\
30-34 \\
>=35 \\
\text { Information not available }\end{array}$ & $\begin{array}{c}5 \\
101 \\
423 \\
574 \\
874 \\
11\end{array}$ & $\begin{array}{c}- \\
- \\
9 \\
27 \\
45\end{array}$ & $\begin{array}{c}- \\
- \\
2.12 \\
4.74 \\
5.14\end{array}$ & $\begin{array}{c}- \\
- \\
0.75-3.50 \\
2.98-6.44 \\
3.68-6.61\end{array}$ & $\begin{aligned} x 2 & =5.512 \\
p & <0.01\end{aligned}$ \\
\hline $\begin{array}{l}\text { Age at marriage completed } \\
\text { years } \\
15-19 \\
20-24 \\
25-29 \\
30-34 \\
>=35 \\
\text { Information not available }\end{array}$ & $\begin{array}{c}59 \\
559 \\
760 \\
429 \\
180 \\
13\end{array}$ & $\begin{array}{l}- \\
07 \\
36 \\
25 \\
13\end{array}$ & $\begin{array}{l}- \\
1.25 \\
4.73 \\
5.83 \\
7.22\end{array}$ & \begin{tabular}{|c|}
$0.32-2.17$ \\
$3.22-6.24$ \\
$3.61-8.04$ \\
$3.44-11.00$
\end{tabular} & $\begin{aligned} x 2 & =17.422 \\
p & <0.001\end{aligned}$ \\
\hline $\begin{array}{l}\text { Ethnicity } \\
\text { Sinhala } \\
\text { Tamil } \\
\text { Muslim } \\
\text { Malay } \\
\text { Other } \\
\text { Information not available }\end{array}$ & $\begin{array}{c}1516 \\
157 \\
242 \\
59 \\
26 \\
3\end{array}$ & $\begin{array}{l}66 \\
06 \\
08 \\
01 \\
-\end{array}$ & $\begin{array}{l}4.35 \\
3.82 \\
3.30 \\
1.69\end{array}$ & $\begin{array}{c}3.32-5.38 \\
0.82-6.82 \\
1.04-5.55 \\
-1.59-4.97\end{array}$ & $\begin{aligned} x 2 & =1.415 \\
p & =0.23\end{aligned}$ \\
\hline $\begin{array}{l}\text { Years of schooling } \\
\text { No schooling } \\
1-5 \\
6-9 \\
10+ \\
\text { Information not available }\end{array}$ & $\begin{array}{c}05 \\
139 \\
816 \\
1036 \\
4\end{array}$ & $\begin{array}{l}- \\
04 \\
26 \\
51\end{array}$ & $\begin{array}{c}- \\
2.88 \\
3.19 \\
4.92\end{array}$ & \begin{tabular}{|l|}
$0.10-5.66$ \\
$1.98-4.39$ \\
$3.60-6.24$
\end{tabular} & $\begin{array}{l}x 2=3.53 \\
p>0.05\end{array}$ \\
\hline $\begin{array}{l}\text { Occupation } \\
\text { Professional } \\
\text { Clerical } \\
\text { Transport } \\
\text { Commercial } \\
\text { Service } \\
\text { Manufacturing } \\
\text { Labourers } \\
\text { Information not available }\end{array}$ & $\begin{array}{c}46 \\
167 \\
51 \\
227 \\
403 \\
75 \\
605 \\
26\end{array}$ & $\begin{array}{l}01 \\
16 \\
08 \\
18 \\
15 \\
05 \\
18\end{array}$ & $\begin{array}{r}2.17 \\
9.58 \\
15.68 \\
7.96 \\
3.72 \\
6.66 \\
2.97\end{array}$ & \begin{tabular}{|c|}
$-2.04-6.38$ \\
$5.11-14.04$ \\
$5.71-25.66$ \\
$4.41-11.44$ \\
$1.87-5.56$ \\
$1.02-12.31$ \\
$1.62-4.32$
\end{tabular} & $\begin{array}{c}x 2=13.99 \\
p<0.05\end{array}$ \\
\hline
\end{tabular}

$\mathrm{CL}=$ Confidence limits

Vol. 45 No. 2, December 2002 
Table 3. Distribution of secondary infertility by selected characteristics of women

\begin{tabular}{|c|c|c|c|c|}
\hline Characteristic & $\begin{array}{l}\text { Number of } \\
\text { women who } \\
\text { have had a } \\
\text { pregnancy }\end{array}$ & $\begin{array}{l}\text { Number of } \\
\text { women with } \\
\text { secondary } \\
\text { infertility }\end{array}$ & $\begin{array}{c}\% \text { of } \\
\text { secondary } \\
\text { infertility }\end{array}$ & $x 2$ for trend \\
\hline $\begin{array}{l}\text { Age group years } \\
15-19 \\
20-24 \\
25-29 \\
30-34 \\
35-39 \\
>=40 \\
\text { Information not available }\end{array}$ & $\begin{array}{c}56 \\
318 \\
515 \\
532 \\
319 \\
166 \\
1\end{array}$ & $\begin{array}{c}01 \\
30 \\
45 \\
97 \\
86 \\
58 \\
3\end{array}$ & $\begin{array}{c}1.78 \\
9.43 \\
8.73 \\
18.23 \\
26.90 \\
34.94\end{array}$ & $\begin{array}{c}x 2=112.4 \\
p<0.000001\end{array}$ \\
\hline $\begin{array}{l}\text { Age at marriage completed } \\
\text { years } \\
15-19 \\
20-24 \\
25-29 \\
30-34 \\
>=35 \\
\text { Information not available }\end{array}$ & $\begin{array}{c}495 \\
759 \\
480 \\
127 \\
43 \\
6\end{array}$ & $\begin{array}{c}89 \\
115 \\
84 \\
16 \\
12 \\
4\end{array}$ & $\begin{array}{c}17.97 \\
15.21 \\
17.50 \\
12.59 \\
27.9\end{array}$ & $\begin{aligned} x 2 & =0.013 \\
p & >0.05\end{aligned}$ \\
\hline $\begin{array}{l}\text { Age at menarche } \\
<14 \text { years } \\
>=14 \text { years } \\
\text { Information not available }\end{array}$ & $\begin{array}{c}939 \\
963 \\
5\end{array}$ & $\begin{array}{c}174 \\
143 \\
2\end{array}$ & $\begin{array}{l}18.53 \\
14.84\end{array}$ & $\begin{array}{c}x 2=4.64 \\
p<0.03\end{array}$ \\
\hline $\begin{array}{l}\text { Ethnicity } \\
\text { Sinhala } \\
\text { Muslim }\end{array}$ & $\begin{array}{c}1441 \\
233\end{array}$ & $\begin{array}{c}268 \\
52\end{array}$ & $\begin{array}{l}18.60 \\
22.30\end{array}$ & $\begin{array}{c}x 2=1.79 \\
p<0.18\end{array}$ \\
\hline $\begin{array}{l}\text { Years of schooling } \\
\text { No schooling } \\
1-5 \\
6-9 \\
10+ \\
\text { Information not available }\end{array}$ & $\begin{array}{c}22 \\
200 \\
827 \\
854 \\
5\end{array}$ & $\begin{array}{c}04 \\
34 \\
130 \\
151 \\
1\end{array}$ & $\begin{array}{l}18.1 \\
17.0 \\
15.7 \\
17.6\end{array}$ & $\begin{array}{c}x 2=0.33 \\
p=0.55\end{array}$ \\
\hline $\begin{array}{l}\text { Occupation } \\
\text { Working } \\
\text { Non working }\end{array}$ & $\begin{array}{c}211 \\
1696\end{array}$ & $\begin{array}{c}29 \\
291\end{array}$ & $\begin{array}{l}13.74 \\
17.16\end{array}$ & $\begin{array}{c}x 2=1.57 \\
p=0.21\end{array}$ \\
\hline
\end{tabular}


Table 4. Distribution of secondary infertility by selected characteristics of the spouse of secondary infertile women

\begin{tabular}{|c|c|c|c|c|}
\hline Characteristic & $\begin{array}{l}\text { Spouses of women } \\
\text { who have had a } \\
\text { previous pregnancy } \\
\text { and are exposed } \\
\text { to the risk of } \\
\text { pregnancy }\end{array}$ & $\begin{array}{c}\text { Number of } \\
\text { spouses with } \\
\text { secondary } \\
\text { infertile } \\
\text { women }\end{array}$ & $\begin{array}{c}\% \text { of spouses } \\
\text { of secondary } \\
\text { infertile } \\
\text { women }\end{array}$ & $x 2$ for trend \\
\hline $\begin{array}{l}\text { Age group years } \\
15-19 \\
20-24 \\
25-29 \\
30-34 \\
35-39 \\
>=40 \\
\text { Information not available }\end{array}$ & $\begin{array}{c}05 \\
101 \\
410 \\
540 \\
382 \\
464 \\
5\end{array}$ & $\begin{array}{c}- \\
09 \\
27 \\
62 \\
80 \\
135 \\
7\end{array}$ & $\begin{array}{c}8.91 \\
6.85 \\
11.48 \\
20.94 \\
29.09\end{array}$ & $\begin{array}{c}x 2=93.53 \\
p<0.000001\end{array}$ \\
\hline $\begin{array}{l}\text { Age at marriage completed } \\
\text { years } \\
15-19 \\
20-24 \\
25-29 \\
30-34 \\
>=35 \\
\text { Information not available }\end{array}$ & $\begin{array}{c}59 \\
546 \\
722 \\
400 \\
167 \\
13\end{array}$ & $\begin{array}{l}08 \\
88 \\
96 \\
80 \\
42 \\
6\end{array}$ & $\begin{array}{l}13.55 \\
16.12 \\
13.69 \\
20.00 \\
25.10\end{array}$ & $\begin{array}{c}x 2=9.16 \\
p<0.05\end{array}$ \\
\hline $\begin{array}{l}\text { Years of schooling } \\
\text { No schooling } \\
1-5 \\
6-9 \\
10+ \\
\text { Information not available }\end{array}$ & $\begin{array}{c}05 \\
133 \\
785 \\
980 \\
5\end{array}$ & $\begin{array}{c}-\cdot \\
30 \\
135 \\
153 \\
2\end{array}$ & $\begin{array}{l}22.55 \\
17.20 \\
15.61\end{array}$ & $\begin{array}{c}x 2=1.91 \\
p>0.05\end{array}$ \\
\hline $\begin{array}{l}\text { Occupation } \\
\text { Professional } \\
\text { Clerical } \\
\text { Transportation workers } \\
\text { Commercial } \\
\text { Service } \\
\text { Labourers } \\
\text { Agriculture workers } \\
\text { Information not available }\end{array}$ & $\begin{array}{c}45 \\
151 \\
43 \\
209 \\
388 \\
587 \\
18 \\
0\end{array}$ & $\begin{array}{c}11 \\
22 \\
37 \\
38 \\
131 \\
76 \\
05 \\
0\end{array}$ & $\begin{array}{l}24.4 \\
14.5 \\
86.1 \\
18.2 \\
33.8 \\
12.9 \\
27.2\end{array}$ & $\begin{array}{l}x 2=151.89 \\
p=0.000001\end{array}$ \\
\hline
\end{tabular}

Vol. 45 No. 2, December 2002 


\section{Discussion}

The study estimated the current point prevalence of primary infertility in the Colombo District to be $4.1 \%$ (95\% C.L. $3.2 \%-4.9 \%$ ). This rate is compatible with rates reported from other Asian countries such as China (3.2\%), Pakistan (4\%), and Korea (2\%) (6) and the estimate of $5.2 \%$ made using data from the Sri Lanka Demographic and Health Survey of 1987 (7).

An appreciable number of couples classified as infertile using the WHO definition of 12 months exposure to risk of pregnancy are likely to achieve a pregnancy spontaneously. On the other hand the definition may be of practical use in clinical practice especially in view of the observed trend in increasing age at marriage.

The study estimated the current point prevalence rate of secondary infertility in the Colombo District to be $16 \%$ (95\% C.L. 14.4\% - 17.6\%). Neighbouring Asian countries report similar rates, Indonesia and Bangladesh have reported a rate of $15 \%$ and Pakistan a rate of $10 \%$ while China has a higher rate $21 \%$ (6). Most African countries report higher rates compared to the Asian situation, the rates varying from $25 \%$ in Tanzania to $33 \%$ in the Cameroon (6). The present study highlights the importance of post-partum and postabortion sepsis in the aetiology of secondary infertility in our population.

Increasing rates of primary and secondary infertility seen with increasing ages of the couple is well documented. The findings of the present study are compatible with references in medical literature that female fertility begins to decline around 30 years of age (8) and a fall in the male fertility potential around 40 years of age (9). Caminiti (1994) identifies age as the most significant factor contributing towards infertility (10). Koetswang et al (11) reported a similar increase in secondary infertility with advancing age among Thai women of the reproductive age group.

Increasing age at marriage in both males and females has been shown to play a role in fertility decline. This may partly be attributed to the fact that women marrying at age 35 years and after find difficulty in conceiving (8). The associations seen with age at marriage, current age of the man and the age at marriage of the man are interrelated. In the present study the male partners of infertile couples were seen to be on an average 4 years older than the female. The increase in infertility associated with increasing age at marriage of the woman, current age and age at marriage of the man are probably mediated through the mechanism of increased infertility with increasing age of the woman.

In the present study the primary infertility rate was seen to increase with increasing level of education in both men and women although not statistically significant. This effect is also probably age related due to postponement of marriage by those who remain in the education process for a longer time. This is also likely to be related to the finding that working women are at higher risk of primary infertility. The secondary infertility rate on the other hand was seen to be higher among those who either had no school education or had studied only up to primary level and among non working women. This may be related to the quality of natal care services available to those in the lower socio economic strata or practices which make them more prone to the risk of infections. Occupation of the man was not associated with secondary infertility. However, the high rates of primary infertility associated with workers in the transport industry warrants further investigation to determine if the nature of employment has any effects on spermatogenesis.

Although inter-country differences and racial differences in infertility have been documented (6) the present study did not find any statistically significant differences in respect of primary infertility. The secondary infertility rate was seen to be higher among women of the Moor community and this may be associated with difference in rates of post-partum or post abortion sepsis or differences in practices associated with childbirth.

Examination of the effect of age at menarche on infertility is justifiable as menarche marks the commencement of the reproductive life of the woman. 
Both primary and secondary infertility were found to increase when menarche was at a younger age although only in, secondary infertility was this difference statistically significant. Perusal of literature did not yield any references to this association.

It is documented that advancing age affects the oocyte in the same manner that aging affects other tissues of the body and it has been identified as one reason for impairment of fertility with advancing age (13). The finding that anovulation is associated with advancing age is also supportive of this theory (14). It may well be that the relationship to chronological age is actually mediated through "reproductive age" i.e. number of years of reproductive life, from menarche to current age and may be a plausible explanation of the association seen with early menarche.

\section{References}

1. Sri Lanka census of Population and Housing, Colombo District Report. Ministry of Plan Implementation, Department of Census and Statistics. 1981; 1: 19-28.

2. Rowe PJ, Farley TMM. Prevention and Management of Infertility. In: Diczfalusy E, Griffin PD, Khanna J, eds. Research in Human Reproduction. World Health Organisation, Biennial Report 1986 - 1987; 265-284.

3. Bennet S., Woods T., Liyanage W.M., Smith D.L. A simplified general method for cluster sample surveys of health in developing countries. World Health Statistics Quarterly 1991; 44: 98-106.

4. World Health Organisation. Prevention of
Infertility. Special programme of Research, Development and Research Training in Human Reproduction. Biennial Report, 1998$1989 ; 67-73$.

5. Some development characteristics of the Sri Lankan adolescent female (I and II). Proceedings of the Sri Lanka Medical Association, 1984.

6. International Planned Parenthood Federation Medical Bulletin. 1990; 24: 1-8.

7. De Silva W. Indralal. The prevalence and aetiology of infertility in Sri Lanka, The Ceylon Journal of Medical Science 1995; 38: 1-10.

8. Browne F.J., Browne Mc Clure. Post Graduate Obstetrics and Gynaecology. London: Butterworths, 1964; p. 391-437.

9. Edward Novak R., Woodruff Donald J., Novaks Gynaecology and Obstetric Pathology $6^{\text {th }}$ edition. Pliladelphia: W.B. Saunders, 1967 p. 211-266.

10. Susan Caminiti. The ordeal of infertility. Fortune 1994; 8: 60-65.

11. Koetswang Suporn, Satyapan Suwanea, Apimas Jivasak Supanee, Belsey Elizabeth M., Pilon A. Prevalence of Infertility in Urban Rural Thailand. Asia Oceania Journal of Obstetrics and Gynaecology 1985; 11: 315-323.

12. Soules Micahel R. Prevention of Infertility. Fertility and Sterility 1988; 49: 82-584.

14. Seperoff Leon, Glass Roger H., Kase Nathan G. Clinical Gynaecologic Endocrinology and Infertility. $4^{\text {th }}$ Edition. London, William and Wilkins, 1988; p. 263-267. 